\title{
IMPLEMENTASI MODEL PEMBELAJARAN TEAM ASSSISTED INDIVIDUALIZATION PADA MATERI UNTUK MENINGKATKAN HASIL BELAJAR PESERTA DIDIK TENTANG MENGIDENTIFIKASI TEKS CERITA PENDEK DI KELAS XI IPS 1 SMAN 2 BOGOR
}

\author{
Sulung Puji Astuti ${ }^{1}$ \\ ${ }^{1}$ SMA Negeri 2 Bogor, Indonesia
}

\begin{abstract}
Abstrak
Penelitian ini bertujuan untuk meningkatkan hasil belajar bahasa Indonesia siswa dengan menerapkan model pembelajaran Kooperatif Tipe TAI (Team Asssisted Individualization) Tentang Megidentifikasi Teks cerita Pendek di Kelas XI IPS SMA Negeri 2 Bogor Semester Ganjil Tahun Pelajaran 2019-2020. Jenis penelitian yang digunakan adalah penelitian tindakan kelas (PTK) yang telah dilakukan dalam dua siklus, masing-masing siklus terdiri atas dua pertemuan yang selalu diakhiri dengan tes akhir siklus. Setiap siklus terdiri atas empat tahap, yaitu tahap perencanaan, tindakan, observasi, dan refleksi. Subjek dalam penelitian ini adalah siswa kelas kelas XI IPS 1 tahun pelajaran 2019/2020 dengan jumlah siswa sebanyak 34 orang. Objek penelitiannya adalah model pembelajaran Kooperatif Tipe TAI (Team Asssisted Individualization). Instrument yang digunakan adalah test hasil belajar berupa soal pilihan berganda.Cara pengumpulan data dalam penelitian ini adalah melalui tes hasil belajar siswa mulai dari prasiklus sampai pada setiap akhir siklus untuk mengetahui peningkatan rata-rata tiap siklus. Sedangkan indikator keberhasilan penelitian ini adalah ketuntasan perorangan dan ketuntasan belajar klasikal atau bersama-sama di dalam kelas. Hasil penelitian menunjukkan adanya peningkatan prestasi hasil belajar. Perolehan nilai rata-rata hasil belajar siswa pada prasiklus dengan ratarata 75,06. Sedangkan pada siklus I dengan menerapkan model pembelajaran Kooperatif Tipe TAI (Team Asssisted Individualization) mengalami peningkatan 4,88 poin menjadi 79,94 . Sedangkan nilai rata-rata di siklus II meningkat 5,24 point dengan rata-rata nilai siklus I ke siklus II menjadi 85,18. Oleh karena itu model pembelajaran Kooperatif Tipe Tai ( Team Asssisted Individualization) yang di sesuaikan dengan materi pembelajaran dapat menciptakan situasi belajar yang menyenangkan sehingga terjadi peningkatan hasil belajar peserta didik.
\end{abstract}

Kata Kunci: Model Pembelajaran Kooperatif Tipe Team Asssisted Individualization; Teks Cerita Pendek; Hasil belajar; Peserta didik.

\section{PENDAHULUAN}

Sistem pendidikan di Indonesia telah menetapkan kurikulum 2013 pada bulan Juli 2013 lalu dan sampai dengan saat ini. Seiring dengan tuntutan perkembangan zaman, perubahan kurikulum di sekolah- sekolah merupakan sebuah fenomena yang tidak dapat dihindari. Sekolah sebagai pelaksana pendidikan, baik pengawas, kepala sekolah, guru, tenaga kependidikan nonguru, maupun siswa sangat berkepentingan dan akan terkena imbasnya secara langsung dari setiap perubahan kurikulum. 
Proses pembelajaran sesuai kurikulum 2013 dengan karakteristik penguatannya mencakup: a) menggunakan pendekatan scientific melalui mengamati, menanya, mencoba, menalar, dan mengomunikasikan dengan tetap memerhatikan karakteristik siswa, b) menggunakan ilmu pengetahuan sebagai penggerak pembelajaran untuk semua mata pelajaran, c) menuntun siswa untuk mencari tahu, bukan diberitahu (discovery learning), dan d) menekankan kemampuan berbahasa sebagai alat komunikasi, pembawa pengetahuan dan berpikir logis, sistematis, dan kreatif. (Depdikbud, 2014:13).

Pada pelaksanaan kurikulum 2013 bahasa Indonesia menjadi penghela ilmu pengetahuan (carrier of knowledge). Pada fungsi ini bahasa menjadi penarik yang mempercepat berkembangnya penguasaan ilmu pengetahuan siswa. Perkembangan pengetahuan siswa seiring dan seirama dengan perkembangan kemampuan berbahasa. Kemahiran menguasai makna dan struktur bahasa Indonesia sekaligus menjadi kekayaan pengetahuannya.

Bahasa Indonesia merupakan salah satu mata pelajaran yang disebut-sebut mengalami perombakan total dalam Kurikulum 2013 ini, selain matematika dan sejarah. Hal ini dilatarbelakangi oleh kenyataan bahwa kemampuan menalar siswa Indonesia masih sangat rendah. Dari studi Trends in International Mathematics and Science Study (TIMSS) tahun 2011, hanya lima persen siswa Indonesia yang mampu memecahkan persoalan yang membutuhkan pemikiran, sedangkan sisanya 95 persen hanya sampai pada level menengah, yaitu memecahkan persoalan yang bersifat hapalan. Dalam implementasinya, pembelajaran bahasa Indonesia menggunakan pendekatan berbasis teks. Teks dapat berwujud teks tertulis maupun teks lisan. Teks merupakan ungkapan pikiran manusia yang lengkap yang di dalamnya memiliki situasi dan konteks. Belajar bahasa Indonesia tidak sekadar memakai bahasa Indonesia untuk menyampaikan materi belajar. Namun, perlu juga dipelajari soal makna atau bagaimana memilih kata yang tepat. Selama ini pembelajaran bahasa Indonesia tidak dijadikan sarana pembentuk pikiran padahal teks merupakan satuan bahasa yang memiliki struktur berpikir yang lengkap. Karena itu pembelajaran bahasa Indonesia harus berbasis teks. Melalui teks maka peran bahasa Indonesia sebagai penghela dan pengintegrasi ilmu lain dapat dicapai.

Materi pembelajaran bahasa Indonesia membuat muatan Kurikulum 2013 penuh struktur teks. Di samping itu, materi sastra yang sangat bermanfaat untuk mengembangkan karakter dan budi pekerti siswa banyak dihilangkan. Kurikulum 2013 melakukan reduksi secara besar-besaran terkait dengan jenis teks sastra. Dari sejumlah kekayaan yang ada dalam khazanah sastra Indonesia, hanya sebagian kecil yang dimasukkan dalam kurikulum. Sastra, selain dapat menggiring anak untuk gemar membaca dan menulis, juga dapat menjadi wahana penanaman nilai-nilai kehidupan bagi manusia yang berbudaya.

Tujuan pembelajaran bahasa Indonesia berbasis teks memang baik. Namun, di lapangan siswa menjadi jenuh karena setiap kali harus berhadapan dengan teks, teks, dan teks. Kejenuhan ini dapat memunculkan permasalahan baru bagi siswa, terlihat dari perolehan prestasi hasil belajar siswa rendah. Ketika peneliti melaksanakan tes awal atau tes prasiklus tentang materi Teks Cerita Pendek di kelas XI IPS 1 hasil yang didapatkan siswa kurang memuaskan. Berdasarkan hasil analisis dari jumlah 34 siswa terdapat 
siswa yang mendapat nilai di atas atau sama dengan KKM ada 11 orang atau sekitar 32,35 $\%$ dan siswa yang belum tuntas atau di bawah KKM ada 23 orang atau sekitar \% dengan rata-rata nilai kelas 75,06 . Sedangkan kriteria ketuntasan minimal (KKM) yang harus dicapai oleh siswa adalah sebagaimana yang sudah ditentukan yaitu 76. Kurangnya pencapaian nilai rata-rata yang dicapai oleh siswa pada umumnya disebabkan karena proses pembelajaran di kelas masih menggunakan metode ceramah sehingga pembelajaran menjadi monoton, pembelajaran di kelas belum dilengkapi dengan media yang sesuai dan memadai. Guru kurang memahami karakter siswa dan kurang maksimal dalam membantu kesulitan siswa dalam memahami materi pelajaran akhirnya siswa mengalami kesulitan dalam bertanya, tidak aktif mengeluarkan pendapat dan yang lebih mengkhawatirkan adalah siswa tidak bersemangat dalam belajar. Berdasarkan latar belakang masalah yang telah diuraikan di atas, maka dapat dirumuskan masalah penelitian, sebagai berikut:

1. Apakah penerapan model pembelajaran kooperatif tipe TAI (Team-AssistedIndividualization) dapat meningkatkan hasil belajar peserta didik tentang mengidentifikasi teks cerita pendek di kelas XI IPS 1 SMA Negeri 2 Bogor semester ganjil tahun pelajarn 2018 - 2019 ?

2. Bagaimana proses penerapan hasil belajar peserta didik tentang mengidentifikasi teks cerita pendek sebelum dan sesudah menggunakan model pembelajaran kooperatif tipe TAI (Team-Assisted-Individualization) di kelas XI IPS 1 SMA Negeri 2 Bogor semester ganjil tahun pelajaran 2018-2019?

3. Seberapa besar peningkatan hasil belajar peserta didik tentang mengidentifikasi teks cerita pendek sebelum menggunakan model pembelajaran tipe TAI di kelas XI IPS 1 SMA Negeri 2 Bogor semester ganjil tahun pelajaran 2018-2019?

\section{METODE PENELITIAN}

Metode yang digunakan dalam penelitian ini adalah penelitian tindakan kelas (PTK). Penelitian tindakan kelas dalam bahasa inggris disebut dengan istilah classroom action research. Makna ketiga kata tersebut menurut Suharsimi dalam Darmadi (2015) adalah sebagai berikut :

1. Penelitian : Kegiatan mencermati suatu obyek dengan cara menggunakan cara dan metodologi tertentu untuk memperoleh data atau informasi yang bermanfaat dalam meningkatkan suatu masalah.

2. Tindakan : Suatu kegiatan yang sengaja dilakukan dengan tujuan tertentu. Dalam penelitian berbentuk rangkaian siklus kegiatan untuk siswa.

3. Kelas : sekelompok siswa yang dalam waktu yang sama, menerima pelajaran yang sama dari guru yang sama pula.

Dengan menggabungkan ketiga kata tersebut menjadi penelitian tindakan kelas (PTK), dapat disimpulkan bahwa Penelitian Tindakan Kelas merupakan suatu pencermatan terhadap kegiatan belajar berupa sebuah tindakan, yang sengaja dimunculkan dan terjadi dalam sebuah kelas secara bersama. Tindakan tersebut diberikan oleh guru atau dengan arahan dari guru yang dilakukan oleh siswa. 
Penelitian Tindakan Kelas merupakan ragam penelitian pembelajaran yang berkonteks kelas yang dilaksanakan oleh guru untuk memecahkan masalah -masalah pembelajaran yang dihadapi oleh guru, memperbaiki mutu dan hasil pembelajaran dan mencoba hal-hal baru dalam pembelajaran demi peningkatan mutu dan hasil pembelajaran. PTK mempunyai karakteristik tersendiri yang membedakan dengan penelitian yang lain, diantaranya yaitu : masalah yang diangkat adalah masalah yang diahadapi oleh guru dikelas dan adanya tertentu untuk memperbaiki proses belajar mengajar dikelas.

Pelaksanaan PTK berfungsi untuk meningkatkan kualitas pendidikan atau pengajaran yang diselenggarakan oleh guru di dalam kelasnya sendiri ketika proses pembelajaran berlangsung dengan tujuan untuk memperbaiki atau meningkatkan kualitas proses mutu dan hasil pembelajaran melalui refleksi diri sehingga hasil belajar peserta didik meningkat atau lebih baik dari sebelumnya. Sebagai subjek dalam penelitian ini adalah siswa kelas XI IPS 1 tahun pelajaran 2019-2020 dengan jumlah siswa sebanyak 34 orang, terdiri atas 16 siswa pria dan siswa 18 wanita. Objek dari penelitian ini adalah aktivitas dan hasil belajar bahasa Indonesia siswa kelas XI IPS 1 SMA Negeri 2 Bogor semester 1 tahun pelajaran 2019-2020 pada materi teks cerita pendek. Penelitian tindakan kelas ini dilaksanakan di SMA Negeri 2 Bogor yang berlokasi di Jalan Kranji Ujung 1 Kelurahan Sukaresmi Kecamatan Tanah Sareal, Kota Bogor pada tahun 2019-2020. Penelitian ini dilaksanakan pada semester ganjil tahun pelajaran 2019-2020, yaitu bulan Juli sampai dengan Desember 2019. Penentuan waktu penelitian mengacu pada kalender akademik sekolah dan jadual pelajaran, karena PTK memerlukan beberapa siklus yang membutuhkan proses belajar mengajar yang efektif di kelas.

Instrumen yang digunakan dalam penelitian ini adalah berupa tes hasil belajar siswa berbentuk pilihan berganda dan lembar observasi untuk mengetahui aktivitas siswa dalam diskusi kelompok untuk mengetahui atau mengukur seberapa besar pemahaman siswa terhadap materi pembelajaran yang disampaikan. Tes hasil belajar yang digunakan disusun dan dikembangkan sendiri oleh peneliti yang mengacu pada standar kompetensi, kompetensi dasar, dan indikator pencapaian kompetensi yang telah dituangkan ke dalam silabus dan dijabarkan dalam RPP. Lembar observasi berisi indikator acuan yang menyatakan perilaku siswa yang dimodifikasi dengan menggunakan Skala Likert. Indikator perilaku siswa yang diamati antara lain: 1. Antusias dalam mengikuti kegiatan pembelajaran. 2. Interaksi antara siswa dengan guru. 3. Interaksi antara siswa dengan siswa. 4. Kerja sama dalam kelompok. 5. Aktivitas siswa dalam diskusi kelompok, dan 6. Partisipasi siswa dalam menyimpulkan materi pembelajaran.

Teknik pengumpulan data yang digunakan dalam penelitian ini adalah data tes hasil belajar bahasa Indonesia siswa kelas XI IPS 1 SMA Negeri 2 Bogor semester dua tahun pelajaran 2019 - 2020. Data tersebut diperoleh dari pelaksanaan tindakan dari setiap siklus berupa hasil belajar melalui tes individu dalam bentuk pilihan berganda pada materi teks ulasan film/drama. Untuk mengukur hasil belajar siswa, tes yang diberikan terdiri atas tes prasiklus dan tes pada setiap akhir siklus. 
Untuk memperoleh data yang sesuai dengan permasalahan dalam penelitian ini, digunakan beberapa teknik dan alat sebagai berikut:

1. Lembar Aktivitas peserta didik

2. Lembar tes pra siklus dan tes siklus

3. Lembar observasi pendidik

4. Daftar nilai

5. Daftar hadir setiap pertemuan

6. Foto yang merupakan rekaman aktivitas belajar

7. Pengamatan lapangan pada saat proses pembelajaran.

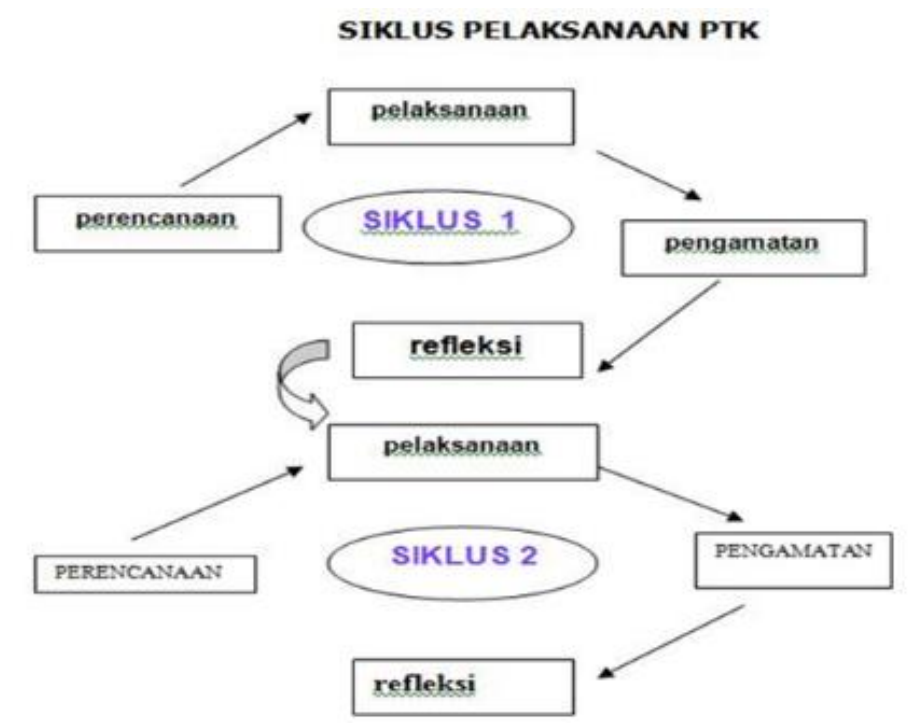

Gambar 1. Alur Penelitian Tindakan Kelas

Berikut adalah rincian prosedur alur tersebut:

Siklus 1:

1. Tahap Perencanaan (Planning), rincian kegiatan pada tahap ini adalah

a. Menyusun rencana pelaksanaan pembelajaran mengacu pada tindakan (treatment) yang diterapkan dalam PTK.

b. Membuat lembar aktivitas siswa sesuai materi pada masing-masing pertemuan

c. Membuat instrumen yang digunakan dalam siklus PTK

d. Menyusun alat evaluasi pembelajaran berupa soal tes akhir Siklus 1

2. Tahap Pelaksanaan (acting)

Pada tahap ini peneliti melakukan deskripsi tindakan yaitu dengan melaksakan pembelajaran di kelas, prosedur tindakan yang dilakukan sebagai berikut:

1. Tahap Kegiatan Awal/Pembuka, kegiatan pembelajarannya adalah:

1) Guru mengondisikan siswa untuk siap belajar dan memotovasi siswa

2) Guru bertanya jawab dengan siswa terkait dengan materi yang akan dipelajari dengan kehidupan saat sekarang.

3) Guru menghubungkan apersepsi dengan materi yang akan disampaikan. 
4) Guru membagi siswa ke dalam kelompok yang beranggotakan 4-5 orang

5) Guru menyampaikan tujuan pembelajaran yang akan dicapai secara lisan.

b. Tahap Kegiatan Inti, kegiatan pembelajarannya adalah:

1) Guru menyajikan materi pembelajaran dengan media interaktif.

2) Guru membimbing dan memotivasi kepada setiap kelompok.

3) Dalam diskusi kelompok tahap pertama, siswa mengerjakan sendiri materi diskusi, guru mengarahkan dan membimbing siswa jika ada kelompok yang mengalami kesulitan.

4) Tahap berikutnya siswa mendiskusikan hasil pekerjaannya dengan kelompoknya untuk menemukan jawaban yang benar.

5) Salah satu dari kelompok diskusi, mempresentasikan hasil kerja kelompoknya

6) Guru memberikan kuis atau pertanyaan

c. Tahap Kegiatan Inti/Penutup, kegiatan pembelajarannya adalah:

1) Siswa diberikan kesempatan untuk memberikan tanggapan terhadap pembelajaran hari ini.

2) Guru dan siswa melakukan penguatan dan simpulan secara bersama-sama

3) Guru menginformasikan tentang materi yang akan dipelajari pada pertemuan berikutnya

3. Tahap Observasi

Dalam penelitian siklus I ini observasi dilakukan terhadap: situasi kegiatan belajar mengajar, keaktifan siswa, dan kemampuan siswa dalam diskusi kelompok. Observasi dilaksanakan oleh Observer satu mata pelajaran, yang terdiri atas dua orang dengan menggunakkan lembar observer yang sudah disiapkan.

\section{Penilaian Evaluasi}

Untuk menentukan nilai rata-rata peserta didik diperoleh dengan cara menjumlah nilai yang diperoleh peserta didik di kelas tersebut. Rumus sederhana yang digunakan untuk merata-rata nilai

Setelah dilaksanakan tes pada setiap akhir siklus, maka data hasil belajar bahasa Indonesia siswa kelas XI IPS 1 dianalisis secara deskriptif sebagai berikut:

a. Nilai Rata-rata Kelas (Mean)

Niai rata-rata (mean) perolehan kelas dihitung dengan menggunakan rumus.

$$
\overline{\mathrm{X}}=\frac{\sum_{i=1}^{n} X_{i} f_{i}}{\sum_{i=1}^{n} f_{i}}
$$

dengan:

$\mathrm{X}^{-}$: nilai rata-rata kelas

$\sum_{i=1}^{n} X_{i} f_{i} \quad$ : jumlah nilai seluruh siswa

$\sum_{i=1}^{n} f_{i}$ : jumlah seluruh siswa 
b. Ketuntasan kelas/klasikal

Ketuntasa klasikal diperoleh dengan menggunakan rumus $\mathrm{KK}=\frac{\sum \text { siswa mencapai KKM }}{\sum f}$ dengan:

KK : ketuntasan klasikal

$\sum f$ : jumlah siswa seluruhnya

\section{HASIL DAN PEMBAHASAN}

Penelitian tindakan kelas ini dilaksanakan dalam dua siklus. Setiap siklus dilaksanakan dalam dua kali pertemuan. Sebelum melaksanakan kegiatan siklus I dan siklus II peneliti memperhatikan kegiatan pembelajaran sebelum dilaksanakan siklus yang disebut pra siklus. Adapun pelaksanaan pra siklus, pelaksanaan dan hasil penelitian siklus I, dan siklus II tersebut adalah sebagai berikut :

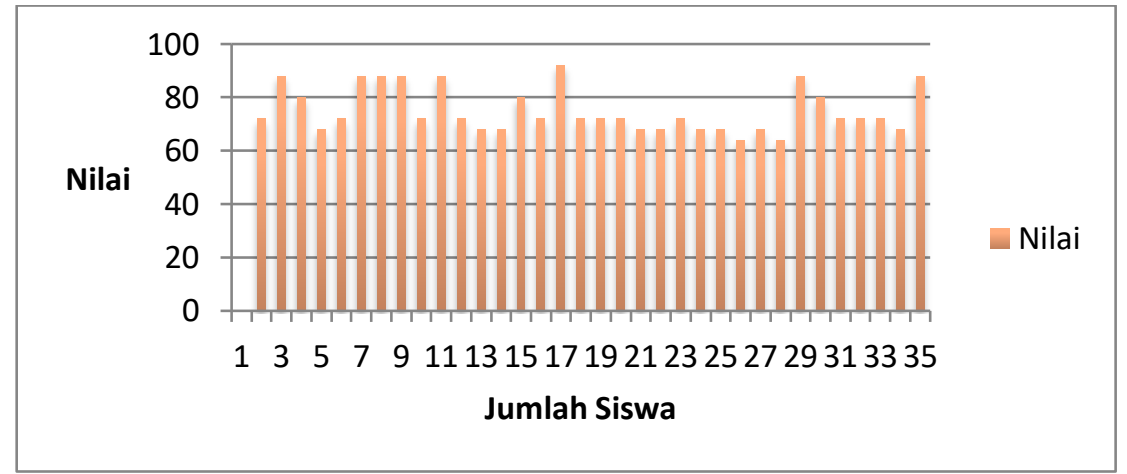

Gambar 2. Hasil Belajar Siswa pada Pra Siklus.

Gambar 2 di atas terlihat bahwa nilai rata-rata hasil belajar siswa adalah 75,06 dengan nilai tertinggi 92 dan nilai terendah 64. Siswa yang mendapat nilai di atas atau sama dengan KKM ada 11 orang atau sekitar 32,35 \% hasil belajar siswa berada di atas KKM. Hal ini memberikan gambaran bahwa hasil belajar siswa pada mata pelajaran bahasa Indonesia masih tergolong rendah.

\section{Deskripsi Hasil Tindakan Siklus I}

1. Perencanaan

a. Sebelum menyusun rencana pembelajaran, peneliti melakukan identifikasi masalah dan merencanakan langkah-langkah yang akan dilaksanakan pada siklus I.

b. Setelah peneliti mengetahui masalah dan langkah-langkah yang akan digunakan pada tindakan di siklus I, peneliti kemudian membuat Rencana Pelaksanaan Pembelajaran (RPP).

c. Menentukan pokok bahasan yang akan dijadikan materi bahasan pada penelitian.

d. Mengembangkan Rencana Pelaksanaan Pembelajaran (RPP).

e. Mengembangkan format evaluasi. berupa penyusunan kisi-kisi soal sampai alat tes tertulis.

f. Mengembangkan format observasi pembelajaran. 
2. Pelaksanaan

Pelaksanaan pembelajaran pada siklus I dilaksanakan pada hari Selasa tanggal 5 November 2019 dan hari Senin 11 tanggal November 2019 di Kelas XI IPS 1 SMA Negeri 2 Bogor dengan jumlah siswa sebanyak 34 orang.

Dalam hal ini peneliti bertindak sebagai pengajar, sedangkan yang bertindak sebagai observer/obsrver adalah Mawarsi,S.Pd. adalah guru bahasa Indonesia SMA Negeri 2 Bogor.

Adapun pembelajaran mengacu pada rencana pelaksanaan pembelajaran yang telah disiapkan. Observeran (observasi) dilaksanakan pada saat pembelajaran berlangsung. Setelah selesai pembelajaran pada siklus I siswa diberi tes akhir siklus I dengan tujuan untuk mengetahui hasil belajar siswa dalam pembelajaran yang telah dilaksanakan. Adapun data hasil belajar pada siklus I dapat dilihat pada Gambar berikut:

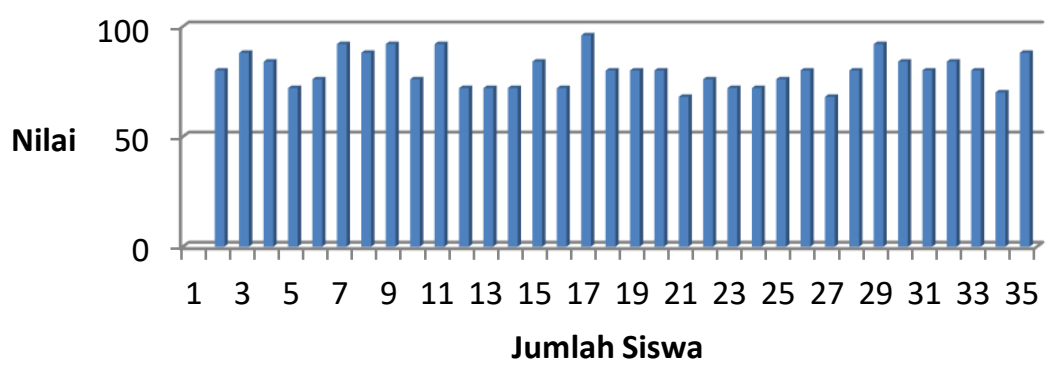

Gambar 3. Hasil Belajar Siswa Pada Pembelajaran Model Pembelajaran Kooperatif Tipe TAI Siklus I

Gambar 3 di atas terlihat bahwa nilai rata-rata hasil belajar siswa adalah 79,94 dengan nilai tertinggi 96 dan nilai terendah adalah 64. Siswa yang mendapat nilai di atas atau sama dengan KKM ada 24 orang atau sekitar 70,59 \% hasil belajar siswa berada di atas KKM. Hal ini memberikan gambaran bahwa ada peningkatan rata-rata hasil belajar siswa dari pra siklus ke siklus I sebesar 4,88 dan ada peningkatan ketuntasan belajar sebesar 38,24\%.

\section{Deskripsi Hasil Tindakan Siklus II}

1. Perencanaan

a. Merevisi perangkat pembelajaran sesuai dengan model pembelajaran kooperatif tipe TAI agar pembelajaran lebih mudah dipahami siswa.

b. Menyiapkan rencana pelaksanaan pembelajaran yang telah direvisi pada kompetensi dasar memahami struktur dan kaidah kebahasaan dalam pemecahan masalah.

c. Menyiapkan lembar aktivitas siswa (LAS).

d. Menyiapkan lembar obserser.

e. Menyiapkan bahan tes hasil belajar.

f. Merancang skenario pelaksanaan tindakan dalam pembelajaran kooperatif tipe TAI. 
2. Pelaksanaan

Pelaksanaan pembelajaran pada siklus II dilaksanakan pada hari Selasa tanggal 19 November 2019 dan hari Senin tanggal 25 November 2019 di Kelas XI IPS 1 SMA Negeri 2 Bogor dengan jumlah siswa sebanyak 34 orang. Dalam hal ini peneliti bertindak sebagai pengajar, sedangkan yang bertindak sebagai observer adalah Mawarsi, S.Pd sebagai guru bahasa Indonesia di SMA Negeri 2 Bogor.

Adapun pembelajaran mengacu pada rencana pelaksanaan pembelajaran yang telah disiapkan. Observeran (observasi) dilaksanakan pada saat pembelajaran berlangsung oleh observer.

Pada akhir pembelajaran siklus II siswa diberi tes akhir siklus II dengan tujuan untuk mengetahui nilai hasil belajar siswa dalam pembelajaran yang telah dilaksanakan. Adapun data hasil belajar pada siklus II dapat dilihat pada Gambar berikut:

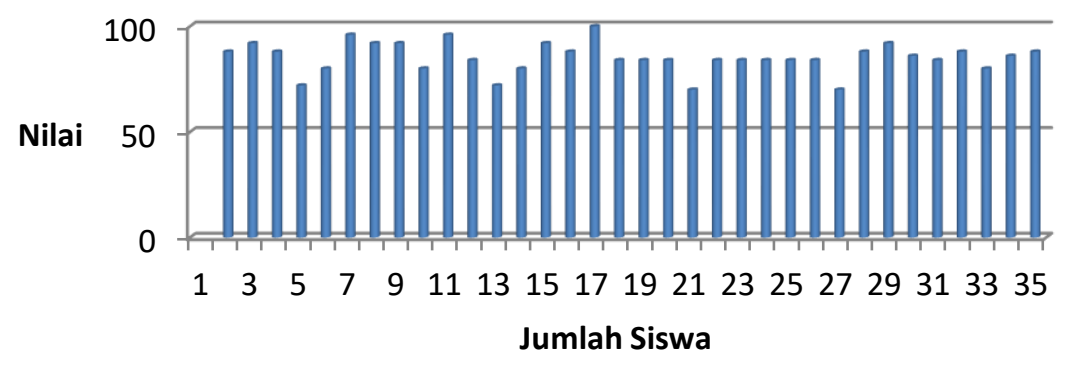

Gambar 4. Hasil Belajar Siswa Pada Pembelajaran Model Pembelajaran Kooperatif Tipe TAI Siklus II

Gambar 4 terlihat bahwa nilai rata-rata hasil belajar siswa adalah 85,18 dengan nilai tertinggi 100 dan nilai terendah adalah 70. Siswa yang mendapat nilai di atas atau sama dengan KKM ada 30 orang atau 88,24 \% dari nilai KKM yang ditetapkan yaitu 76 . Hal ini memberikan gambaran bahwa ada peningkatan rata-rata hasil belajar siswa dari siklus I ke siklus II sebesar 5,24 dan ada peningkatan ketutasan belajar sebesar 17,65\%.

Berdasarkan hasil penelitian selama dua siklus yang bertujuan untuk meningkatkan hasil belajar siswa pada kompetensi dasar memahami struktur dan kaidah kebahasaan teks cerita pendek, terlihat pada pelaksanaan siklus pertama dan kedua telah menunjukkan peningkatan. Pada penerapan model pembelajaran kooperatif tipe TAI, interaksi siswa dan guru di awal pelajaran diawali oleh guru dengan pembentukan kelompok, tiap siswa mempunyai tanggung jawab terhadap kelompoknya, serta siswa dapat berlajar secara aktif dan menyenangkan. Kemudian guru mengarahkan dan menjelaskan bagaimana siswa belajar dengan baik dalam kelompoknya. Saat proses pembelajaran berlangsung, guru mengelola kelas secara interaktif, membimbing siswa, dan memotivasi siswa untuk aktif berperan dalam kegiatan pembelajaran. Pada akhir pelajaran, guru bersama siswa menyimpulkan pembelajaran yang telah dilaksanakan. Kemudian guru mengevaluasi siswa dengan memberikan soal yang sesuai dengan kompetensi dasar. Berdasarkan hal tersebut, dapat disimpulkan bahwa telah ada peningkatan hasil belajar dan aktivitas siswa dalam pembelajaran bahasa Indonesia.Hasil penelitian menunjukkan bahwa kemampuan siswa dalam memahami materi pelajaran 
Implementasi Model Pembelajaran Team Asssisted Individualization Pada Materi Untuk Meningkatkan Hasil Belajar Peserta Didik Tentang Mengidentifikasi Teks Cerita Pendek di Kelas XI IPS 1 SMAN 2 Bogor

dalam pembelajaran melalui penerapan model pembelajaran kooperatif tipe TAI secara keseluruhan menunjukan adanya peningkatan. Rincian dari peningkatan tersebut adalah:

1. Peningkatan Hasil Belajar

Pembelajaran melalui penerapan model penerapan model pembelajaan kooperatif tipe TAI dapat meningkatkan hasil belajar dari pra siklus ke siklus I kemudian ke siklus II dapat dilihat dari rekapitulasi hasil belajar pada Gambar berikut:

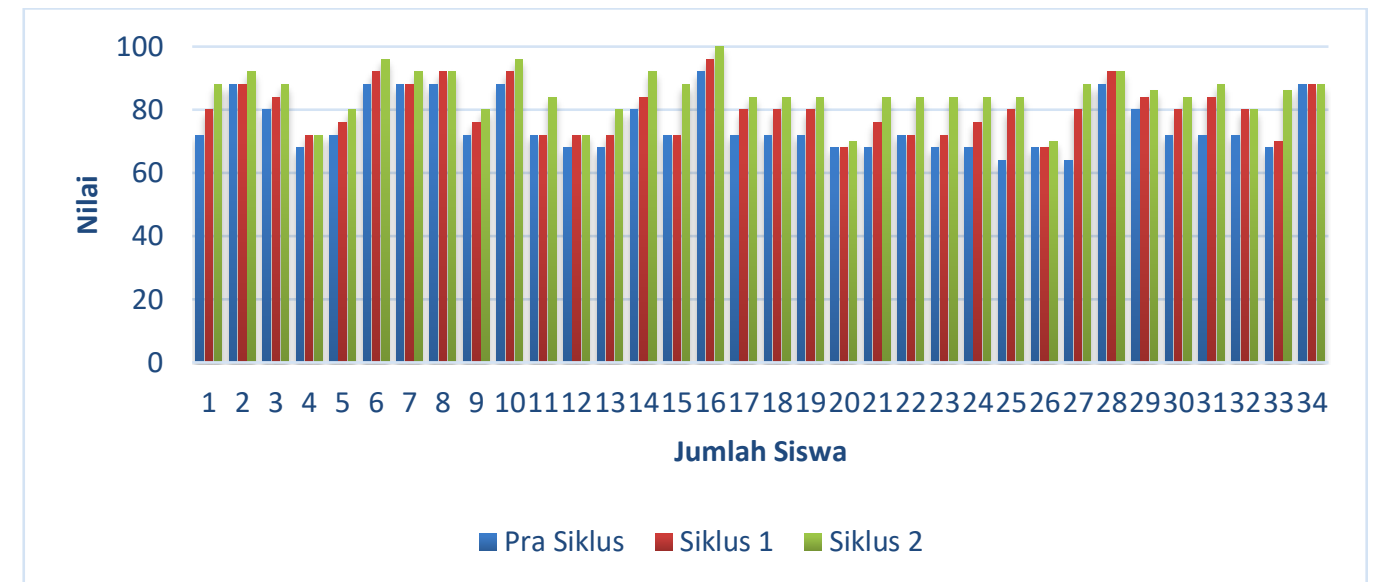

Gambar 5. Peningkatan Hasil Belajar Siswa pada Pra Siklus,Siklus I, dan Siklus II

Dari Gambar 5 terlihat jelas terjadi peningkatan hasil belajar dari pra siklus ke siklus I dan dari siklus I ke siklus II. Warna hijau pada Gambar 5 menunjukkan hasil belajar pada siklus II yang berada di atas dua warna lainnya. Artinya pada siklus II terjadi peningkatan yang signifikan.

2. Peningkatan Rata-rata Hasil Belajar

Pembelajaran melalui penerapan model pembelajaran kooperatif tipe (TAI) dapat meningkatkan rata-rata hasil belajar siswa. Peningkatan hasil belajar dari pra siklus, siklus I, dan siklus II terlihat dari Gambar berikut:

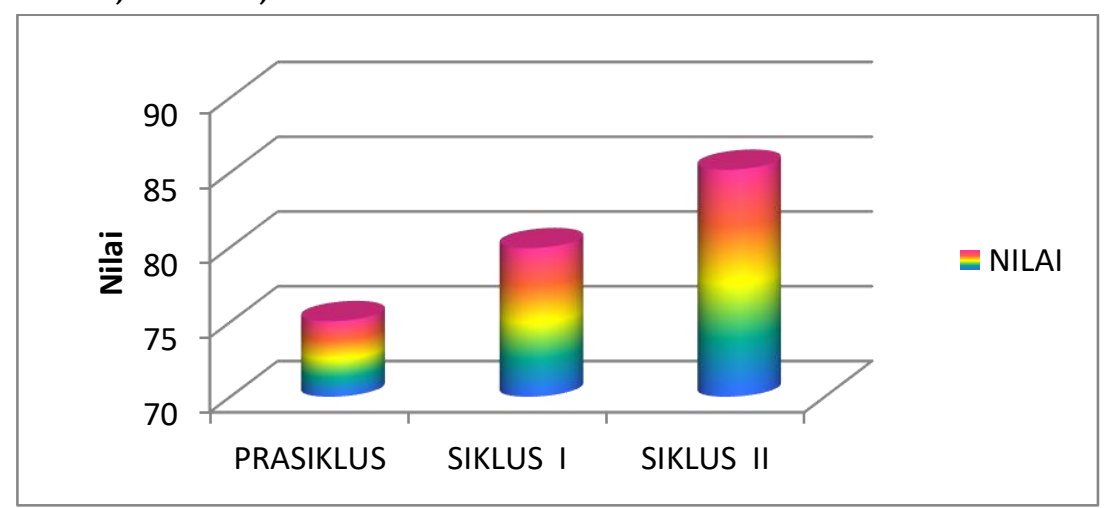

Gambar 6. Peningkatan Nilai Rata-rata Hasil Belajar Siswa dari Pra Silkus, Siklus I, dan Siklus II

Dari Gambar 6 terlihat adanya peningkatan nilai rata-rata hasil belajar dari pra siklus ke siklus I dan dari siklus I ke siklus II yaitu dari 75,06 menjadi 79,94 dan dari 79,94 menjadi 85,18. 
3. Peningkatan Ketuntasan Hasil Belajar

Pembelajaran melalui penerapan model pembelajaran kooperatif tipe TAI dapat meningkatkan ketuntasan hasil belajar siswa, hal ini terlihat dari Gambar 4.6 bahwa terjadi peningkatan persentase peningkatan ketuntasan hasil belajar dari pra siklus, siklus I, dan siklus II.

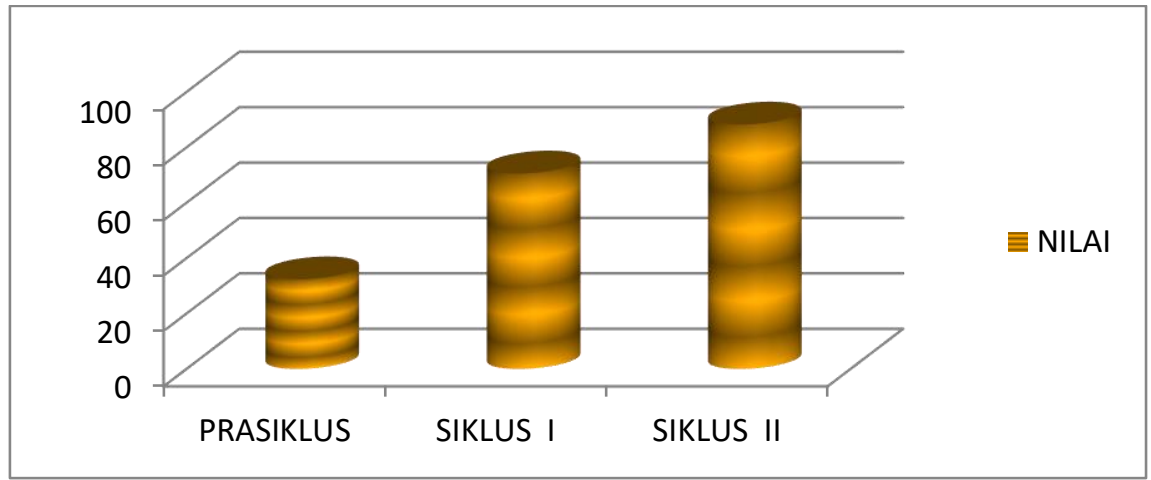

Gambar 7. Presentase Peningkatan Ketuntasan Belajar

Gambar 7 menunjukkan bahwa telah terjadi peningkatan ketuntasan hasil belajar dari 32,35 \% yang tuntas pada pra siklus menjadi 70,58 \% pada siklus I dan meningkat lagi ketuntasan belajar siswa menjadi 88,24 \%. Dari keterangan di atas memperlihatkan bahwa penerapan model pembelajaran kooperatif tipe TAI dapat meningkatkan hasil belajar. Karena katuntasan klasikal sudah mencapai 88,24\%, artinya sudah melebihi 85\%, maka penelitian dianggap sudah cukup.

\section{KESIMPULAN}

Berdasarkan hasil penelitian tindakan kelas yang telah dilaksanakan pada siklus I dan siklus II dengan menerapkan model pembelajaran kooperatif tipe TAI (Team Assisted Individualization), diperoleh simpulan sebagai berikut:

1. Penerapan model pembelajaran kooperatif tipe TAI dapat meningkatkan hasil belajar tentang mengidentifikasi Teks Cerita Pendek pada siswa kelas XI IPS 1 SMA Negeri 2 Bogor. Hal ini dapat dilihat dari nilai rata-rata hasil belajar siswa yang mengalami peningkatan dari 79,94 pada siklus I menjadi 85,18 pada siklus II, prosentase ketuntasan hasil belajar juga mengalami peningkatan 32,35\% yang tuntas pada pra siklus menjadi 70,59\% pada siklus I mengalami peningkatan lagi menjadi $88,24 \%$ pada siklus II.

2. Berdasarkan hasil penelitian selama dua siklus yang bertujuan untuk meningkatkan hasil belajar siswa pada kompetensi dasar memahami struktur dan kaidah kebahasaan teks cerita pendek ,berdasarkan hal tersebut, dapat disimpulkan bahwa telah ada peningkatan hasil belajar dan aktivitas siswa dalam pembelajaran bahasa Indonesia.Hasil penelitian menunjukkan bahwa kemampuan siswa dalam memahami materi pelajaran dalam pembelajaran melalui penerapan model pembelajaran kooperatif tipe TAI secara keseluruhan menunjukan adanya peningkatan

3. Penerapan model pembelajaran kooperatif tipe TAI bisa mengarahkan siswa untuk mengembangkan keterampilan sosial dan meningkatkan kinerja siswa 
dalam tugas-tugas kelompok maupun individu serta meningkatkan keaktifan siswa dalam mengikuti pembelajaran.

4. Penerapan model pembelajaran kooperatif tipe TAI dalam pembelajaran menjadi menyenangkan, membuat siswa tidak bosan, dan tidak jenuh sehingga aktivitas belajar siswa meningkat. Hal tersebut berpengaruh terhadap hasil belajar yang dicapai siswa.

\section{DAFTAR PUSTAKA}

Fathoni, Abdurrahmat. 2005. Metodologi Penelitian dan Teknik Penyusunan Skripsi. Jakarta: Rineka Cipta.

Kurniawan, Budi. Model Pembelajaran Kooperatif. https://kurniawanbudi04.wordpress.com/2013/05/27/model-pembelajarankooperatif-cooperatif-learning/

Mahsun. 2014. Teks Dalam Pembelajaran Bahasa Indonesia Kurikulum 2013. Jakarta: RajaGrafindo Persada.

Marahimin, Ismail. 1994. Menulis Secara Populer. Jakarta: Pustaka Jaya.

Mujiono, Dimyati. 2006. Belajar dan Pembelajaran.Jakarta: Rineka Cipta.

Mukhtar. 2007. Bimbingan Skripsi, Tesis, dan Artikel Ilmiah: Panduan Berbasis Penelitian Kualitatif Lapangan dan Perpustakaan. Jakarta: Gaung Persada Press.

Muslihuddin. 2010. Kiat Sukses Melakukan Penelitian Tindakan Kelas dan Sekolah. Bandung: Rizqi Press.

Nasution, S. dan M. Thomas. 2005. Buku Penuntun Membuat Tesis, Skripsi, Desertasi, Makalah. Jakarta: Bumi Aksara.

Pusat Bahasa. Departemen Pendidikan Nasional. 2003. Kamus Besar Bahasa Indonesia. Jakarta: Balai Pustaka.

Rusman. 2010. Model-model Pembelajaran Mengembangkan Profesionel Guru. Jakarta: Prestasi Pustaka.

Sukarnyana, I Wayan. 2002. Penelitian Tindakan Kelas. Departemen Pendidikan Nasional.

Sulistyo - Basuki. 2006. Metode Penelitian. Jakarta: Wedatama Widya Sastra.

Undang, Gunawan. 2009. Lesson Study Model Pengkajian Pembelajaran Kolaboratif. Bandung: Rizqi Press. 